\title{
The benefits of Functional Movement Screen in judo
}

\author{
Jožef ŠIMENKO* \\ ${ }^{1}$ University of Essex, Essex Pathways Department, Colchester (United Kingdom)
}

8th IMACSSS International Conference Abstracts, Viseu (Portugal), October 10-12, 2019

Type: Oral communication

\begin{abstract}
With the development of screening methods, simple screening tools could commonly be used to assess movement quality in real-world conditions. One of those methods is the functional movement screen (FMS), that was developed to helps determine the fundamental movement patterns of an individual. FMS test was administered to 9 elite judokas aged $22 \pm 4.24$ years, height $176.44 \pm 7.44$ and weight $79.44 \pm 15.92 \mathrm{~kg}$. The overall FMS score was $17.56 \pm 1.59$. No significant asymmetries were noted in the bilateral test. The lowest score was achieved in shoulder mobility $1.89 \pm 0.6$ which represent and issue that needs to be addressed to prevent the occurrence of injuries. Overall the FMS testing could be a beneficial tool to strength and conditioning coaches in judo, especially in the preseason to assess the functional movement status of judo athletes and to address any issues that could be identified. It represents a fast and affordable screening tool, but it needs to be administered by a qualified assessor. The data of this study could serve as a reference score to other FMS research in judo or other combat sports or martial arts.
\end{abstract}

Keywords: Martial arts; combat sports; FMS; asymmetries; prevention; screening; test.

\section{Introduction}

In elite sports, usually in laboratory settings, complex and expensive methods are being used to enable accurate measurements. With the development of screening methods, simple screening tools could commonly be used to assess movement quality in real-world conditions (Kraus, Schütz, Taylor, \& Doyscher, 2014). In an attempt to translate a motion assessment tool into daily sports practice, the functional movement screen (FMS) was developed. It helps to assess the fundamental movement patterns of an individual (Cook, Burton, Hoogenboom, \& Voight, 2014a; Kraus et al., 2014). The FMS ${ }^{\mathrm{TM}}$ is comprised of seven fundamental movement patterns (tests) that require a balance of mobility and stability (including neuromuscular/motor control) (Cook et al., 2014a) and include movement tasks that assess hip flexion, external, and internal rotation, as well as core stability and abduction/adduction of the shoulder joints (Kraus et al., 2014). In judo, FMS has not been widely used as our research shows only four papers on it (Boguszewski, Buda, Adamczyk, \& Białoszewski, 2017; Ciz, Štefanovský, Matejová, \& Lopata, 2017; Jerman, Dolenc, \& Šimenko, 2017; Šimenko, 2012). Till now it was used on recreational judokas (Jerman et al., 2017) and in elite judo athletes (Boguszewski et al., 2017; Ciz et al., 2017; Šimenko, 2012). Higher FMS scores in judo have been shown to positively correlate with a higher number of victories and to distinguish between medalist and non-medalist groups (Boguszewski et al., 2017).

\section{Objectives}

Our study aimed to measure functional movement on elite male judokas and to add research data to the FMS usage in the field of judo to be used by researchers or coaches.

\section{Methodology}

The participants of the study were nine judo athletes aged $22 \pm 4.24$ years, height $176.44 \pm$ 7.44 , and weight $79.44 \pm 15.92 \mathrm{~kg}$. They had a training experience of at least five years, and eight athletes had DAN degree, and one athlete had $1 \mathrm{KYU}$ belt degree. All of the participants where

*Email: j.simenko@essex.ac.uk 
Categorized athletes, according to Slovenian Olympic Committee regulations and were active competitors licensed by the Slovenian Judo Association and were regularly competing in international competitions. All subjects were informed about the study procedures and signed written informed consent.

The FMS test was carried out before exercise or warm-up from 10-12 am in the clubs of participants. The subject performs a given task three times, and the rater evaluates the best performance (Boguszewski et al., 2017). The screening was done by a qualified FMS evaluator. The FMS is composed of the following seven exercises which test basic movement pat-terns: deep squat, hurdle step, in-line lunge, shoulder mobility, active straight leg raise (ASLR), trunk stability pushup, and rotary stability (Cook et al., 2014a). The performance of each of the tests listed above was assessed on a four-point scale according to predefined criteria. The subject can receive from 0 to 3 points for each movement where he receives 3 points if the movement was carried out correctly, 2 points if it was completed with compensation, 1 point if the subject could not perform the movement or with high compensation, and 0 points if they experienced pain when making the movement or during the pain provocation test. The maximum total number of points that could be achieved in the FMS screen is 21 (Cook et al., 2014a; Cook, Burton, Hoogenboom, \& Voigh, 2014b).

Analyses were conducted using SPSS for Windows (Version 25.0; SPSS, Inc., Chicago, USA). Data are presented according to descriptive statistics (Means \pm SD). Differences between the results obtained for the left and right side of the body (in the case of bilateral tests) were analyzed using the Wilcoxon signed-rank test. All statistical significance was set to $p<.05$.

\section{Results}

In table 1 , the data shows us that the final score of judokas is $17.56 \pm 1.59$. The highest scores were achieved in the Trunk stability push-up $3 \pm 0$, the In-line lounge $3 \pm 1$ and Active straight leg raise $2.89 \pm 0.33$. The worst result was obtained in the shoulder mobility test, with a score of $1.89 \pm 0.6$. There were no significant differences between bilateral tests which represent good symmetry of functional movement between body sides.

Table I. Descriptive statistics and asymmetries in bilateral tests of FMS screening

\begin{tabular}{|c|c|c|c|c|c|c|c|c|c|c|c|c|c|c|c|c|c|c|}
\hline \multirow[t]{2}{*}{ Test } & \multirow[t]{2}{*}{$\begin{array}{l}\text { Deep } \\
\text { squat }\end{array}$} & \multicolumn{3}{|c|}{$\begin{array}{c}\text { Hurdle } \\
\text { step }\end{array}$} & \multicolumn{3}{|c|}{$\begin{array}{l}\text { In-line } \\
\text { lunge }\end{array}$} & \multicolumn{3}{|c|}{$\begin{array}{l}\text { Shoulder } \\
\text { mobility }\end{array}$} & \multicolumn{3}{|c|}{$\begin{array}{c}\text { Active straight } \\
\text { leg raise }\end{array}$} & \multirow{2}{*}{$\begin{array}{c}\text { Trunk } \\
\text { stability } \\
\text { push-up }\end{array}$} & \multicolumn{3}{|c|}{$\begin{array}{c}\text { Rotary } \\
\text { stability }\end{array}$} & \multirow[t]{2}{*}{$\begin{array}{l}\text { Total } \\
\text { score }\end{array}$} \\
\hline & & $\mathbf{L}$ & $\mathbf{R}$ & $\mathbf{F}$ & $\mathbf{L}$ & $\mathbf{R}$ & $\mathbf{F}$ & $\mathbf{L}$ & $\mathbf{R}$ & $\mathbf{F}$ & $\mathbf{L}$ & $\mathbf{R}$ & $\mathbf{F}$ & & $\mathrm{L}$ & $\mathrm{R}$ & $\mathrm{F}$ & \\
\hline$M$ & 2.67 & 2.22 & 2 & 2 & 3 & 2.9 & 3 & 2 & 2 & 1.89 & 2.9 & 2.9 & 2.89 & 3 & 3 & 3 & 2.44 & 17.56 \\
\hline$S D$ & 0.5 & 0.44 & 0 & 0 & 1 & 0.3 & 1 & 1 & 0.71 & 0.6 & 0.3 & 0.3 & 0.33 & 0 & 0 & 1 & 0.53 & 1.59 \\
\hline
\end{tabular}

L-left side, R-right side, F-final score of bilateral test, ${ }^{*}$ Statistical significant differences between sides.

\section{Discussion and Conclusion}

One of the important factors that impacts on performance outcome in competitions of combat sports and judo is the athletes' health condition and their susceptibility to injury. That is why identifying risk factors and implementing preventive measures is important not only in the context of health and quality of life, but also with regard to performance outcomes in sports (Lockie et al., 2015; Okada, Huxel, \& Nesser, 2011). Therefore, FMS fits perfectly in this description as it checks functional movement asymmetries between different parts of the body and from the total score, gives an assessment of movement, which helps us to prevent the occurrence of injuries (Šimenko, 2012). The overall FMS score of 17.56 was higher than the scores of Polish elite judokas (medalist group) 15.52 and non-medalist group 13.91 (Boguszewski et al., 2017). Similar but lower FMS score was found in elite Slovak judokas with the FMS score 17 (Ciz et al., 2017) and Slovenian judokas 16.94 (Šimenko, 2012) but in those studies the sample was comprised from males and females. Our data also highlight an issue in shoulder mobility in elite judokas that needs to be addressed which is in line with current research where shoulder injuries represent $22 \%$ of all injuries in judo (Pocecco et al., 2013). Overall the FMS testing could be a beneficial tool to strength and conditioning coaches in judo especially in the preseason to assess the functional movement status of athletes and to address any issues that could be identified. The testing battery is easy to use, and it does not need any special testing equipment. Testing should be administered by a 
qualified assessor. If the assessor has doubts which score to give, he should always go for the lower score. The data of this study could serve as a reference score to other FMS research in judo or other combat sports or martial arts.

\section{References}

Boguszewski, D., Buda, M., Adamczyk, J. G., \& Białoszewski, D. (2017). Relationship between functional limitations of the locomotor system and performance in judo. Polish Journal of Sport and Tourism, 24(3), 145-149. doi: 10.1515/pjst-2017-0015

Ciz, I., Štefanovský, M., Matejová, L., \& Lopata, P. (2017). Functional movement screening of elite judokas. In M. Chren, K. Péliová, \& E. Sulovská (Eds.), Nové vedecké poznatky v gymnastike, tancoch, úpoloch, fitnes a silových športoch (pp. 13-19). Bratislava.

Cook, G., Burton, L., Hoogenboom, B. J., \& Voight, M. (2014a). Functional movement screening: the use of fundamental movements as an assessment of function - Part 1. International Journal of Sports Physical Therapy, 9(3), 396-409.

Cook, G., Burton, L., Hoogenboom, B. J., \& Voight, M. (2014b). Functional Movement Screening: The Use of Fundamental Movements as an Assssment of Function - Part 2. International Journal of Sports Physical Therapy, 9(4), 549-563.

Jerman, P., Dolenc, M., \& Šimenko, J. (2017). Movement efficiency of recreational judokas. Šport: Revija Za Teoreticna in Prakticna Vprasanja Sporta, 65(1/2), 120-123.

Kraus, K., Schütz, E., Taylor, W. R., \& Doyscher, R. (2014). Efficacy of the Functional Movement Screen. Journal of Strength and Conditioning Research, 28(12), 3571-3584. doi: 10.1519/ISC.0000000000000556

Lockie, R. G., Schultz, A. B., Jordan, C. A., Callaghan, S. J., Jeffriess, M. D., \& Luczo, T. M. (2015). Can Selected Functional Movement Screen Assessments Be Used to Identify Movement Deficiencies That Could Affect Multidirectional Speed and Jump Performance? Journal of Strength and Conditioning Research, 29(1), 195-205. doi: 10.1519/ISC.0000000000000613

Okada, T., Huxel, K. C., \& Nesser, T. W. (2011). Relationship Between Core Stability, Functional Movement, and Performance. Journal of Strength and Conditioning Research, 25(1), 252261. doi: $10.1519 /$ JSC.0b013e3181b22b3e

Pocecco, E., Ruedl, G., Stankovic, N., Sterkowicz, S., Del Vecchio, F. B., Gutiérrez-García, C., ... Burtscher, M. (2013). Injuries in judo: a systematic literature review including suggestions for prevention. British Journal of Sports Medicine, 47(18), 1139-1143. doi: 10.1136/bjsports-2013-092886

Šimenko, J. (2012). Analysis of movement efficiency of judoists. Šport: Revija Za Teoreticna in Prakticna Vprasanja Sporta, 60(3), 85-89. 